\section{Pesticide exposure and health conditions of terrestrial pesticide applicators in Córdoba Province, Argentina}

\author{
Exposición a plaguicidas y condiciones de salud \\ de agroaplicadores terrestres de la Provincia de \\ Córdoba, Argentina
}

\section{Exposição aos agrotóxicos e condições de saúde dos aplicadores de pesticidas da Província de Córdoba, Argentina}

\author{
Mariana Butinof 1 \\ Ricardo Antorio Fernandez 2 \\ María Inés Stimolo 3 \\ María Josefina Lantieri 1 \\ Marcelo Blanco 4 \\ Ana Lia Machado 5 \\ Germán Franchini 1 \\ María del Pilar Díaz ${ }^{1}$
}

1 Facultad de Ciencias Médicas, Universidad Nacional de Córdoba, Córdoba, Argentina.

2 Facultad de Medicina

Universidad Católica de Córdoba, Córdoba, Argentina.

3 Facultad de Ciencias

Económicas, Universidad

Nacional de Córdoba,

Córdoba, Argentina.

4 Facultad de Ciencias

Agropecuarias, Universidad

Nacional de Córdoba

Córdoba, Argentina.

5 Facultad de Psicología,

Universidad Nacional de

Córdoba, Córdoba, Argentina.

Correspondence

M. Butinof

Escuela de Nutrición,

Facultad de Ciencias

Médicas, Universidad

Nacional de Córdoba.

Edificio Escuelas de Ciencias

Médicas, E. Barros $s / n$.

2o piso, Córdoba 5000

Argentina.

mariana@butinof.com.ar

\begin{abstract}
Agricultural workers represent a population that is highly vulnerable to the toxic effects of pesticide exposure. This cross sectional study aimed to describe the health conditions of terrestrial pesticide applicators in Córdoba Province, Argentina, their work practices and socio-demographic characteristics, by means of a standardized self-administered questionnaire $(n=880)$. A descriptive analysis reported $a$ high prevalence of occasional or frequent symptoms: $47.4 \%$ had symptoms of irritation, 35.5\% fatigue, $40.4 \%$ headache and $27.6 \%$ nervousness or depression. Using logistic regression models, risk and protective factors were found for symptoms of irritation, medical consultation and hospitalization. Among the occupational exposure variables, marital status, length of time in the job, low level of protection with regard to the use of personal protective equipment, combined use of different pesticides and the application of the insecticide endosulfan, were associated with a higher frequency of reported symptoms and higher consultation rates and hospitalization.
\end{abstract}

Pesticides; Occupational Diseases; Occupational Exposure

\section{Resumen}

Los trabajadores agrícolas son una población altamente vulnerable a los efectos tóxicos de la exposición a plaguicidas. Con el objetivo de describir las condiciones de salud de agroaplicadores terrestres de plaguicidas de la Provincia de Córdoba, Argentina, sus prácticas laborales y características sociodemográficas, se realizó un estudio transversal, mediante cuestionario $(n=880)$. Un análisis descriptivo reportó alta prevalencia de sintomatología ocasional o frecuente: $47,4 \%$ síntomas irritativos, 35,5\% cansancio, 40,4\% cefalea y 27,6\% ansiedad o depresión. Mediante modelos logísticos se detectaron factores protectores y de riesgo que explican la presencia de síntomas irritativos, la consulta médica y la hospitalización. El estado civil, la antigüedad en la tarea, el nivel de protección considerando uso de equipo de protección personal, la exposición múltiple a plaguicidas y la aplicación del insecticida endosulfán, se asociaron a mayor frecuencia de reporte de síntomas, consultas médicas y hospitalizaciones por causas relacionadas con la exposición a plaguicidas.

Plaguicidas; Enfermedades Profesionales; Exposición Profesional 


\section{Introduction}

The rapid expansion of agriculture in Argentina, as in other developing countries, has taken on a new dimension as a result of the increasing flow of agricultural products and foods for export. Argentina has increased the area planted for grains, particularly soybeans, from 34,700 ha in the 1969/1970 season, to about 18 million hectares at present (Sistema Integrado de Información Agropecuaria. Estimaciones agrícolas. Datos de la Dirección de Información Agrícola y Forestal. http://www.siia. gov.ar/series, accessed on 08/Jun/2013). Córdoba, a province of Argentine, is no different to the rest of the country: agriculture accounts for $48.02 \%$ of the farming area 1 , with an expansion of extensive crops (soybeans, corn, wheat, peanuts, sorghum and sunflower) from $3,397,050$ ha in 1994/1995 to 7,208,700ha in 2011/2012 (http://www.siia.gov.ar/ series, accessed on $08 / \mathrm{Jun} / 2013$ ), with soybeans accounting for $80 \%$ of production. The expansion of the agricultural frontier has led to significant degradation of native forests, $85 \%$ of which have disappeared in the northern plains and hills of Córdoba over a period of 30 years ${ }^{2}$.

The technological farming model used in the region requires increasing amounts of chemicals, mainly herbicides, to control pests; pesticide marketing has grown markedly, from 155 million pounds in 1995 to 700 million pounds in $2012{ }^{3}$. However, given that only 10 percent of applied pesticides reach the target organism, a high percentage is deposited on non-targeted areas (soil, water and sediments), affecting public health and non-targeted organisms ${ }^{4}$. In developed countries, studies have demonstrated the annual incidence rates of acute pesticide poisoning in agricultural workers to be as much as 18.2 per 100,000 full time workers and 7.4 per million among schoolchildren. In developing countries, the incidences are expected to be higher, due to insufficient regulation, lack of surveillance systems, less enforcement, lack of training, inadequate access to information systems, poorly maintained or nonexistent personal protective equipment, and larger agriculturally-based populations 5 .

The effects on health depend on various factors related to the product, the characteristics of the exposure and the condition of the host. Short exposure to some pesticides can cause poisoning of varying severity and is potentially lethal 6 ; it is short-term, can be geographically limited, and is generally related to a single pesticide 7 . The impact on health of low-level chronic exposure is less well-known; however, there are many studies reporting associations with cancer, neurological deficits, endocrine disruption, immune disorders, birth defects, fertility problems and reproductive disorders 8,9,10.

Pesticide exposure in rural areas affects a sector of the population that is highly exposed and very vulnerable 11 , and constitutes one of the biggest health problems in rural communities 12 . In the Province of Córdoba, exposure to different pesticides linked to agricultural production has been recognized 13. Our previous results of a population-based study in the province, of terrestrial applicators of pesticides in extensive crops, emphasized that workers were highly exposed to pesticides. Laxity in complying with the rules governing the activity was also highlighted as a factor that increases the health risk of agricultural workers and the general population 14 .

Research to evaluate these populations and initiate the study of risk factors associated with occupational exposure and the consequent damage to health contributes to detecting population groups with biological and social vulnerability, and to planning appropriate public policies for monitoring, prevention and control. The absence of other Argentine population-based studies that recognize the characteristics and magnitude of the problem have led to the development of this study.

The objective was to describe and study the health status of terrestrial applicators in the Province of Córdoba, in relation to their work practices and socio-demographic characteristics.

\section{Methods}

\section{Study population and data collection}

A population-based study of terrestrial pesticide applicators working in extensive crops was conducted in the Province of Córdoba, which is located in the center of the country, covering $165,321 \mathrm{~km}^{2}$ (approximately $8 \%$ of Argentina). It is the second most populated province $(3,367,000$ inhabitants; 18.5 inhabitants $/ \mathrm{km}^{2}$ ), its population is $80 \%$ urban, and towns with fewer than 5,000 inhabitants are located in the north of the province.

All workers who took part in the survey attended mandatory courses provided by the Agriculture, Livestock and Food Ministry in order to obtain their applicator license, between 2007 and 2010. The courses were held in different locations of the province covering the entire territory. After explaining the purpose of the study and obtaining prior informed consent, a self-administered questionnaire (adapted from the Agricultural Health Study 15) was applied. Exposure determinants, including characteris- 
tics that may influence exposure levels 16, were covered.

From a universe of approximately 3,500 subjects, a random sample of about 1,100 workers directly exposed to pesticides was performed, considering as such those subjects who mix/load and/or apply pesticides. A consistency analysis for various responses was carried out on 1,122 completed forms, leaving a sample size of 880 applicators directly exposed to pesticides for further analysis (only terrestrial applicators of extensive crops were included, while aerial pesticide applicators were excluded). As mentioned, applicators are professional workers authorized by the Agriculture, Livestock and Food Ministry to perform their tasks. They usually work in several extensive crops in the same area of the province, as independent professionals (the owners of the machinery) or as employees of an agrarian company.

Questionnaire reliability was measured through Cronbach's alpha index, which was equal to 0.95 .

\section{Variables}

The questionnaire consisted of five modules: demographic data, pesticide use, crop information, lifestyle and health conditions of workers and their families. In this study, socio-demographic and work practice variables were selected as exposure characteristics. Socio-demographic variables were age (in years, calculated from the respondent's date of birth); marital status (married or cohabiting, separated or divorced, widowed, single); educational level reached (incomplete primary, complete primary, incomplete secondary, complete secondary or above); proximity of housing to crops (up to $500 \mathrm{~m}$, more than $500 \mathrm{~m}$, according to the distance set by the Provincial Agrochemical Act. 9,164 for crop-spraying near homes).

As regards working practices, the frequency of pesticide use was studied, assessing the type and number of pesticide products applied (a checklist of 49 specific pesticides currently in use and of forbidden chemicals or restricted-use chemicals with their common and trade names was included to enhance recall); years in the job; the application technology used, with the categories: (a) use of crop sprayers or self-propelled machines with sealed, pressurized cabin, with air entering only through an activated charcoal filter; (b) crop sprayer or self-propelled machine without a cabin or that has a cabin that does not meet the previously listed specifications; and (c) backpack; the level of personal protection was evaluated through the use of personal protective equipment (PPE), weighting each implement in the PPE based on the score proposed by Dosemeci et al. 17, adapted locally by Lantieri et al. 13; a person was considered adequately protected if he or she wore waterproof clothing, chemical-resistant gloves, a gas mask, a face shield or goggles and boots, giving $90 \%$ protection from exposure; other workers were considered inadequately protected, with levels ranging from 0 to $70 \%$ protection. Finally, participants were asked about the existence of an agrochemical prescription signed by an agronomist (yes/no).

The following variables were surveyed to study the health conditions of workers associated with, or as a result of, occupational exposure to pesticide: perception of symptoms that appear after the beginning of the exposure (a) symptoms of irritation (irritation of skin, eyes, nausea, vomiting, respiratory disorders), (b) fatigue, (c) nervousness or depression, (d) headache, with the following frequency: never or rarely, sometimes or often; medical consultation (yes/no), and prevalence of hospitalizations (yes/no) for job-related reasons. The hospital discharge rate was estimated with data of patient discharge 18 (males 15 to 64 years old from Córdoba province) and the census population for the same period (Instituto $\mathrm{Na}$ cional de Estadística y Censos. Cobertura de salud años 2004-2008. http://www.indec.mecon. ar/principal.asp?id_tema $=71$, accessed on 04/ Feb/2011) (specific for sex and age group); the base population was adjusted with a factor of 0.46 , corresponding to the proportion of the population attending public hospitals in the period.

\section{Statistical analysis}

The population was characterized by a descriptive statistics analysis. The population of terrestrial pesticide applicators was split into two categories - adequately protected and inadequately protected considering the adoption of PPE during occupational exposure. Independency hypotheses (chi-square tests) were calculated to two-dimensional contingency tables between symptoms and health assistance and demographic and exposure characteristics. Logistic regression models (generalized binary models) 19 were estimated for the symptoms and health assistance, including socio-demographic variables, work characteristics and symptoms of the applicators as explanatory factors. We selected the models with the best performance (the selection of variables was performed with a backward stepwise procedure using the log likelihood criterion; entry $\mathrm{p}=0.05$, removal $\mathrm{p}=0.10$ ) to identify protective or risk factors. Data analysis was performed using the SPSS 11.5.1 software (SPSS Inc., Chicago, USA). 


\section{Ethical considerations}

The study was approved by the Ethics Research Committee of the Clinics National Hospital, Faculty of Medical Sciences, University of Córdoba. All participants were included in an informed consent process and accepted to participate voluntarily and freely. All data was encrypted for legal and confidentiality purposes.

\section{Results}

The study population consisted of young rural workers $($ mean $=34.9, \mathrm{SD}=11.05), 17.8 \%$ were under 25 at the time of the study, 20\% were over 45 and only $5.4 \%$ were over 54 (Table 1). $98.9 \%$ were Argentine white males and $63.5 \%$ were currently married or cohabiting. Generally, they were not migrant workers: $89.9 \%$ were born in Córdoba. With regard to educational attainment, $11.8 \%$ had not completed primary school, $36.3 \%$ had completed primary school and $25.6 \%$ had completed

Sociodemographic and work characteristics of pesticide terrestrial applicators. Córdoba Province, Argentina, 2007-2010.

\begin{tabular}{|c|c|c|}
\hline & $\mathbf{n}$ & Valid (\%) * \\
\hline \multicolumn{3}{|l|}{ Age (years) } \\
\hline $14-24$ & 149 & 17.8 \\
\hline $25-34$ & 314 & 37.5 \\
\hline $35-44$ & 207 & 24.7 \\
\hline 45 and over & 167 & 20.0 \\
\hline \multicolumn{3}{|l|}{ Education } \\
\hline Incomplete primary & 88 & 11.8 \\
\hline Complete primary & 271 & 36.3 \\
\hline Incomplete secondary & 196 & 26.3 \\
\hline Complete secondary, technical or university studies & 191 & 25.6 \\
\hline \multicolumn{3}{|l|}{ Marital Status } \\
\hline Married or cohabiting & 474 & 63.5 \\
\hline Unmarried, separated, divorced or widower & 273 & 36.5 \\
\hline \multicolumn{3}{|l|}{ Proximity to the nearest treated crop of the applicators household } \\
\hline Less than $500 \mathrm{~m}$ & 316 & 46.5 \\
\hline $500 \mathrm{~m}$ or more & 364 & 53.5 \\
\hline \multicolumn{3}{|l|}{ Time in the job (mixing/applying pesticides in years) } \\
\hline$\leq 1$ & 122 & 14.2 \\
\hline $2-5$ & 298 & 34.8 \\
\hline $6-10$ & 201 & 23.4 \\
\hline $11-20$ & 162 & 18.9 \\
\hline$>20$ & 75 & 8.6 \\
\hline \multicolumn{3}{|l|}{ Application technology used } \\
\hline $\begin{array}{l}\text { Crop sprayers or self-propelled machines with sealed, pressurized cabin, } \\
\text { with activated charcoal filter (yes) }\end{array}$ & 435 & 71.9 \\
\hline Crop sprayer or self-propelled machine without activated charcoal filter (yes) & 256 & 46.9 \\
\hline Backpack (yes) & 254 & 36.0 \\
\hline \multicolumn{3}{|l|}{ Written pesticide prescription by an agricultural engineer } \\
\hline Received a written prescription (yes) & 123 & 14.0 \\
\hline \multicolumn{3}{|l|}{ Level of protection (use of PPE) } \\
\hline Not using any PPE & 126 & 14.3 \\
\hline Using some PPE & 466 & 53.0 \\
\hline Adequately use of PPE & 288 & 32.7 \\
\hline
\end{tabular}

PPE: personal protective equipment.

* Percentage considering the total valid responses. 
secondary education. Regarding the location of the applicators' residence, $46.5 \%$ lived within $500 \mathrm{~m}$ of the nearest crop, while $25.7 \%$ lived less than $100 \mathrm{~m}$ away. With respect to length of time in employment, $91.4 \%$ of terrestrial pesticide applicators had up to 20 years of exposure. While some had started work at 14 years of age, they generally abandoned it at an early age, with only $8.6 \%$ of the study population remaining in the job for over 20 years. Only $32.9 \%$ of the study population was adequately (i.e. 90\%) protected through the use of PPE during mixing and/or application; $14.3 \%$ reported not using any PPE during application practices.

The analysis of the working practices reveals, in regard to the application equipment, that $71.9 \%$ of workers used towed or self-propelled machinery with a sealed, pressurized cabin, admitting air through a charcoal filter. $36 \%$ reported using a backpack for spraying agrochemicals. Each worker normally uses two or more types of equipment to apply chemicals. The presence of a prescription signed by an agronomist at the time of application is mentioned in only $14 \%$ of cases.

With regard to the type and frequency of pesticide use (Table 2), herbicides were reported as the most common, with glyphosate (98\%), 2,4-D (89.3\%) and atrazine (87.4\%) applied the most. The insecticides used most were cypermethrin (94.7\%), followed by chlorpyrifos (78.2\%) and endosulfan (69.2\%). Among the fungicides, the association epoxiconazole + pyraclostrobin was used by $34.6 \%$, while carbendazim was next in order of importance $(30 \%)$. The study of their combined use reveals that on average the applicators used about 11 different pesticides ( $\mathrm{SD}=5.2$ ), and in some cases up to 26 (range 1 to 26 ).

The study of workers' health status reflects the high prevalence of symptoms: $47.4 \%$ reported sometimes or frequently having symptoms of irritation, $35.5 \%$ fatigue or tiredness, $40.4 \%$ headaches and $27.6 \%$ anxiety or depression. Medical consultations related to their work exposure, on at least one occasion, was recorded by $35.6 \%$ of respondents, and requiring hospitalization on at least one occasion among $5.4 \%$ (Table 3). In a bivariate analysis, the presence of symptoms of irritation was associated with time in the job ( $p$ $=0.03$ ), a lack of proper protection considering the use of PPE ( $p=0.04)$, lower participation of professional agronomists in making out the phytosanitary application prescription $(p=0.06)$ and the combination of 10 or more pesticides ( $p<$ 0.01 ). The presence of headaches was associated with the lack of adequate protection $(p=0.03)$, the use of backpacks as application technology ( $\mathrm{p}=$ 0.02 ), the combination of 10 or more pesticides ( $p$ $<0.01$ ) and age, the most frequent being between the ages of 35 and $44(p=0.01)$. The presence of
Table 2

Pesticide most frequently used by terrestrial applicators

Córdoba Province, Argentina, 2007-2010.

\begin{tabular}{|c|c|c|}
\hline & $\mathrm{n}$ & Valid (\%) * \\
\hline \multicolumn{3}{|l|}{ Herbicides } \\
\hline Glyphosate & 858 & 98.5 \\
\hline $2,4 \mathrm{D}-2,4 \mathrm{DB}$ & 810 & 93.5 \\
\hline Atrazine & 799 & 92.2 \\
\hline Metsulfuron & 706 & 82.3 \\
\hline Dicamba & 587 & 69.4 \\
\hline Acetochlor & 524 & 60.9 \\
\hline Metolachlor & 440 & 51.8 \\
\hline Picloram & 392 & 46.0 \\
\hline \multicolumn{3}{|l|}{ Insecticides } \\
\hline Cypermethrin & 829 & 95.7 \\
\hline Chlorpyrifos & 705 & 82.1 \\
\hline Endosulfan & 638 & 75.6 \\
\hline Dimethoate & 526 & 65.8 \\
\hline Deltamethrin & 516 & 60.8 \\
\hline \multicolumn{3}{|l|}{ Fungicides } \\
\hline $\begin{array}{l}\text { Pyraclostrobin + } \\
\text { Epoxiconazole }\end{array}$ & 299 & 37.8 \\
\hline $\begin{array}{l}\text { Azoxystrobin + } \\
\text { Ciproconazole }\end{array}$ & 241 & 36.7 \\
\hline $\begin{array}{l}\text { Carbendazim + } \\
\text { Epoxiconazole }\end{array}$ & 272 & 34.3 \\
\hline Carbendazim & 277 & 33.0 \\
\hline Thiram & 163 & 19.5 \\
\hline
\end{tabular}

* Percentage of total valid responses.

nervousness or depression tended to increase in those who had not properly protected themselves.

The report of increased frequency of medical consultation related to occupational exposure was associated with time in the job $(\mathrm{p}<0.01)$, multiple exposures (more than ten pesticides) $(\mathrm{p}<0.01)$; with age, being more frequent among young adults (34 to 44 years); with marital status, increasing among those married or cohabiting $(\mathrm{p}<0.01)$. Paradoxically, it was also greater among those who were adequately $(90 \%)$ protected $(p=0.03)$, those using the safer application technology $(p=0.02)$ and with higher levels of education $(p=0.02)$. In this population, the distance from the dwelling to the nearest crop was not associated with the prevalence of symptoms, or with the frequency of medical consultations or hospitalizations.

The association between the exposure to each pesticide and symptoms as well as health assistance was studied. The use of insecticides was associated with several symptoms and the procurement of health assistance: symptoms of irritation 
Table 3

Association results of prevalence of symptoms and health assistance and its relationship with variables related to occupational exposure and demographic characteristics among pesticide applicators. Córdoba Province, Argentina, 2007-2010.

\begin{tabular}{|c|c|c|c|c|c|c|}
\hline \multirow{6}{*}{$\begin{array}{l}\text { Occupational exposure } \\
\text { and demographic } \\
\text { characteristics }\end{array}$} & \multicolumn{6}{|c|}{ Symptoms and health assistance } \\
\hline & Signs of Irritation & Fatigue/Tiredness & Headache & $\begin{array}{c}\text { Nervousness or } \\
\text { depression }\end{array}$ & $\begin{array}{c}\text { Medical } \\
\text { consultation }\end{array}$ & Hospitalization \\
\hline & Never/Rarely: & Never/Rarely: & Never/Rarely: & Never/Rarely: & Never: 64.4 & Never: 94.6 \\
\hline & 52.6 & 64.5 & 59.6 & 72.4 & & \\
\hline & Sometimes/ & Sometimes/ & Sometimes/ & Sometimes/ & Once or more: & Once or more: 5.4 \\
\hline & Frequently: 47.4 & Frequently: 35.5 & Frequently: 40.4 & Frequently: $\mathbf{2 7 . 6}$ & 35.6 & \\
\hline \multirow{2}{*}{\multicolumn{7}{|c|}{$\begin{array}{l}\text { Seniority in the job } \\
\text { (years) * }\end{array}$}} \\
\hline & & & & & & \\
\hline$\leq 10$ & 45.2 & 35.2 & 39.2 & 26.6 & 32.2 & 4.6 \\
\hline \multirow[t]{2}{*}{$>10$} & 54.9 & 37.8 & 43.2 & 31.4 & 44.6 & 8.1 \\
\hline & $p=0.03$ & $p=0.52$ & $p=0.35$ & $p=0.24$ & $p<0.01$ & $p=0.07$ \\
\hline \multicolumn{7}{|l|}{$\begin{array}{l}\text { Level of protection } \\
\text { (use of PPE) }\end{array}$} \\
\hline Protected & 41.6 & 33.7 & 34.6 & 23.5 & 41.0 & 4.9 \\
\hline \multirow{2}{*}{$\begin{array}{l}\text { Partially or } \\
\text { unprotected * }\end{array}$} & 50.2 & 36.4 & 43.2 & 29.6 & 33.0 & 5.6 \\
\hline & $p=0.04$ & $p=0.48$ & $p=0.03$ & $p=0.10$ & $p=0.03$ & $p=0.68$ \\
\hline \multicolumn{7}{|l|}{$\begin{array}{l}\text { Agrochemical } \\
\text { prescription signed by an } \\
\text { agronomist * }\end{array}$} \\
\hline Yes & 37.8 & 28.0 & 32.6 & 23.2 & 34.5 & 7.1 \\
\hline \multirow[t]{2}{*}{ No } & 48.8 & 36.6 & 41.5 & 28.3 & 35.7 & 5.1 \\
\hline & $p=0.06$ & $p=0.105$ & $p=0.11$ & $p=0.33$ & $p=0.81$ & $p=0.41$ \\
\hline \multicolumn{7}{|l|}{$\begin{array}{l}\text { Application technology } \\
\text { used * }\end{array}$} \\
\hline \multirow[t]{2}{*}{ Crop sprayer ** } & 45.2 & 40.0 & 43.6 & 27.6 & 38.7 & 4.6 \\
\hline & $p=0.93$ & $p=0.36$ & $p=0.38$ & $p=0.64$ & $p=0.02$ & $p=0.51$ \\
\hline \multirow[t]{2}{*}{ Backpack } & 47.7 & 37.6 & 36.5 & 23.9 & 39.8 & 5.1 \\
\hline & $p=0.72$ & $p=0.54$ & $p=0.02$ & $p=0.18$ & $p=0.20$ & $p=0.58$ \\
\hline Mixed or applied more & 51.5 & 37.8 & 44.6 & 29.3 & 40.3 & 6.2 \\
\hline than 10 pesticides * & $p<0.01$ & $p=0.07$ & $p<0.01$ & $p=0.12$ & $p<0.01$ & $p=0.17$ \\
\hline \multicolumn{7}{|l|}{ Insecticides * } \\
\hline \multirow[t]{2}{*}{ Chlorpyrifos } & 50.9 & 37.1 & 41.7 & 28.5 & 39.2 & 6.2 \\
\hline & $p<0.01$ & $p=0.08$ & $p=0.21$ & $p=0.34$ & $p<0.01$ & $p=0.05$ \\
\hline \multirow[t]{2}{*}{ Endosulfan } & 50.0 & 37.3 & 41.1 & 29.4 & 39.9 & 6.6 \\
\hline & $p=0.03$ & $p=0.11$ & $p=0.58$ & $p=0.10$ & $p<0.01$ & $p=0.02$ \\
\hline \multirow[t]{2}{*}{ Cypermethrin } & 48.6 & 36.1 & 41.2 & 28.5 & 36.3 & 5.8 \\
\hline & $p=0.04$ & $p=0.26$ & $p=0.15$ & $p=0.08$ & $p=0.14$ & $p=0.06$ \\
\hline \multicolumn{7}{|l|}{ Age (years) * } \\
\hline $14-24$ & 45.4 & 39.7 & 39.8 & 28.0 & 26.1 & 5.8 \\
\hline $25-34$ & 48.1 & 33.3 & 37.3 & 25.1 & 31.0 & 4.5 \\
\hline $35-44$ & 49.0 & 34.3 & 49.7 & 26.8 & 47.1 & 6.9 \\
\hline \multirow[t]{2}{*}{45 and over } & 43.6 & 32.6 & 32.8 & 30.8 & 39.0 & 5.6 \\
\hline & $p=0.31$ & $p=0.15$ & $p=0.01$ & $p=0.41$ & $p<0.01$ & $p=0.87$ \\
\hline
\end{tabular}

(continues) 


\begin{tabular}{|c|c|c|c|c|c|c|}
\hline \multirow{6}{*}{$\begin{array}{l}\text { Occupational exposure } \\
\text { and demographic } \\
\text { characteristics }\end{array}$} & \multicolumn{6}{|c|}{ Symptoms and health assistance } \\
\hline & Signs of Irritation & Fatigue/Tiredness & Headache & $\begin{array}{l}\text { Nervousness or } \\
\text { depression }\end{array}$ & $\begin{array}{c}\text { Medical } \\
\text { consultation }\end{array}$ & Hospitalization \\
\hline & Never/Rarely: & Never/Rarely: & Never/Rarely: & Never/Rarely: & Never: 64.4 & Never: 94.6 \\
\hline & 52.6 & 64.5 & 59.6 & 72.4 & & \\
\hline & Sometimes/ & Sometimes/ & Sometimes/ & Sometimes/ & Once or more: & Once or more: 5.4 \\
\hline & Frequently: 47.4 & Frequently: 35.5 & Frequently: 40.4 & Frequently: 27.6 & 35.6 & \\
\hline \multicolumn{7}{|l|}{ Marital status * } \\
\hline Married/Cohabiting & 45.2 & 35.1 & 41.9 & 28.8 & 38.8 & 5.8 \\
\hline Unmarried/Separated & 50.9 & 35.2 & 37.9 & 27.7 & 28.2 & 4.3 \\
\hline \multicolumn{7}{|l|}{ Divorced/Widower } \\
\hline & $p=0.18$ & $p=0.96$ & $p=0.32$ & $p=0.77$ & $p<0.01$ & $p=0.42$ \\
\hline \multicolumn{7}{|l|}{ Education level * } \\
\hline Incomplete primary & 42.5 & 25.4 & 29.2 & 29.1 & 26.0 & 2.8 \\
\hline Complete primary & 44.5 & 35.6 & 40.4 & 24.0 & 39.7 & 7.0 \\
\hline Incomplete secondary & 51.4 & 40.2 & 43.6 & 34.2 & 40.9 & 5.6 \\
\hline \multirow{4}{*}{$\begin{array}{l}\text { Complete secondary, } \\
\text { technical or university } \\
\text { studies }\end{array}$} & 54.4 & 34.3 & 43.6 & 33.3 & 30.0 & 3.4 \\
\hline & & & & & & \\
\hline & & & & & & \\
\hline & $p=0.20$ & $p=0.21$ & $p=0.19$ & $p=0.16$ & $p=0.02$ & $p=0.34$ \\
\hline \multirow{2}{*}{\multicolumn{7}{|c|}{$\begin{array}{l}\text { Proximity of housing to } \\
\text { crops * }\end{array}$}} \\
\hline & & & & & & \\
\hline Less than $500 \mathrm{~m}$ & 44.8 & 38.0 & 42.5 & 30.1 & 33.6 & 3.7 \\
\hline \multirow[t]{2}{*}{$500 \mathrm{~m}$ or more } & 47.4 & 35.7 & 41.3 & 26.1 & 37.0 & 5.3 \\
\hline & $p=0.55$ & $p=0.56$ & $p=0.77$ & $p=0.31$ & $p=0.37$ & $p=0.35$ \\
\hline
\end{tabular}

PPE: personal protective equipment.

* Prevalence of the symptom within the row subpopulation;

** Crop sprayer or self-propelled machines with sealed, pressurized cabin, with activated charcoal filter.

with the use of chlorpyrifos $(\mathrm{p}<0.01)$, endosulfan $(\mathrm{p}=0.03)$ and cypermethrin $(\mathrm{p}=0.04)$; medical consultation with the use of chlorpyrifos $(p<0.01)$ and endosulfan $(p<0.01)$ and hospitalization for reasons related to occupational exposure was associated with the use of chlorpyrifos $(p=0.05)$ and endosulfan $(\mathrm{p}=0.02)$.

The logistical models selected have determined the protective or risk factors. The presence of symptoms of irritation has the following risk factors (Table 4): medical consultation $(\mathrm{OR}=1.96$; $\mathrm{CI}$ : 1.31-2.94), nervousness or depression $(\mathrm{OR}=4.39$; CI: 2.83-6.80), being single, a widower or divorced $(\mathrm{OR}=1.61$; CI: 1.07-2.40), as well as being more than ten years on the job (OR = 1.65; CI: 1.05-2.59) and having mixed or applied more than 10 pesticides (OR = 1.56; CI: 1.04-2.35); the adequate use of PPE was a protective factor for these symptoms $(\mathrm{OR}=0.61$; CI: 0.40-0.92). One or more medical consultations was associated with the presence of symptoms of nervousness or depression (OR = 1.89; CI 1.20-2.99), fatigue or tiredness ( $\mathrm{OR}=1.69$; CI: 1.11-2.58) and symptoms of irritation (OR = 1.75; CI: 1.16-2.65). Also the adequate use of PPE
$(\mathrm{OR}=1.58$; CI: 1.05-2.37) and the application of the insecticide endosulfan $(\mathrm{OR}=2.10$; CI: 1.32 3.35). Those who were not married or cohabiting were less likely to visit the doctor $(\mathrm{OR}=0.65$; $\mathrm{CI}$ : 0.44-0.98). Hospitalization for reasons related to pesticide exposure was associated with the presence of symptoms of irritation $(\mathrm{OR}=3.37$; CI: 1.398.16) and headaches (OR $=2.66$; CI: $1.20-5.90)$ as well as applying the pesticide endosulfan (OR = 2.74; CI: 0.94-8.04).

\section{Discussion}

The present technological model applied in food production requires the application of increasing amounts of agrichemical products 3 , leading to risks to human health and to the environment $4,11,20$.

The population of pesticide applicators in our cohort reported a significant burden of disease related to their occupational exposure to pesticides, as has been described previously 21 . 
Table 4

Results of binary logistic regression model adjusting for the variables irritation symptoms, medical consultation and hospitalization, related to occupational exposure to pesticides. Córdoba Province, Argentina., 2007-2010.

\begin{tabular}{|c|c|c|c|}
\hline & Categories & OR $(95 \% \mathrm{Cl})$ & $\mathrm{p}$-value \\
\hline \multicolumn{4}{|c|}{ Did you present symptoms of irritation? } \\
\hline \multicolumn{4}{|l|}{ Independent variables } \\
\hline \multirow[t]{2}{*}{ Consulted a medical doctor? } & Never & 1.00 & 0.00 \\
\hline & Once or more & $1.96(1.31 ; 2.94)$ & \\
\hline \multirow[t]{2}{*}{ Nervousness or depression } & Never or rarely & 1.00 & 0.00 \\
\hline & Sometimes or frequently & $4.39(2.83 ; 6.80)$ & \\
\hline \multirow[t]{2}{*}{ Marital status } & Married or cohabiting & 1.00 & 0.02 \\
\hline & Unmarried, separated, divorced or widower & $1.61(1.07 ; 2.40)$ & \\
\hline \multirow[t]{2}{*}{ Use of PPE } & Without proper protection & 1.00 & 0.02 \\
\hline & Adequately protected (minimum 90\%) & $0.61(0.40 ; 0.92)$ & \\
\hline \multirow[t]{2}{*}{ Seniority in the job } & Up to 10 years & 1.00 & 0.03 \\
\hline & More than 10 years & $1.65(1.05 ; 2.59)$ & \\
\hline \multirow[t]{2}{*}{ Mixed or applied } & Up to 10 pesticides & 1.00 & 0.03 \\
\hline & More than 10 pesticides & $1.56(1.04 ; 2.35)$ & \\
\hline \multicolumn{4}{|l|}{ Did you consult a medical doctor? } \\
\hline \multicolumn{4}{|l|}{ Independent variables } \\
\hline \multirow[t]{2}{*}{ Nervousness or depression } & Never or rarely & 1.00 & 0.06 \\
\hline & Sometimes or frequently & $1.89(1.20 ; 2.99)$ & \\
\hline \multirow[t]{2}{*}{ Fatigue/Tiredness } & Never or rarely & 1.00 & 0.02 \\
\hline & Sometimes or frequently & $1.69(1.11 ; 2.58)$ & \\
\hline \multirow[t]{2}{*}{ Symptoms of irritation } & Never or rarely & 1.00 & 0.01 \\
\hline & Sometimes or frequently & $1.75(1.16 ; 2.65)$ & \\
\hline \multirow[t]{2}{*}{ Marital status } & Married or cohabiting & 1.00 & 0.04 \\
\hline & Unmarried. separated. divorced o widower & $0.65(0.44 ; 0.98)$ & \\
\hline \multirow[t]{2}{*}{ Use of PPE } & Without proper protection & 1.00 & 0.03 \\
\hline & Adequately protected (minimum 90\%) & $1.58(1.05 ; 2.37)$ & \\
\hline \multirow[t]{2}{*}{ Endosulfan } & Did not apply & 1.00 & 0.01 \\
\hline & Applied & $2.10(1.32 ; 3.35)$ & \\
\hline \multicolumn{4}{|l|}{ Have you been hospitalized? } \\
\hline \multicolumn{4}{|l|}{ Independent variables } \\
\hline \multirow[t]{2}{*}{ Symptoms of irritation } & Never or rarely & 1.00 & 0.01 \\
\hline & Sometimes or frequently & $3.37(1.39 ; 8.16)$ & \\
\hline \multirow[t]{2}{*}{ Headache } & Never or rarely & 1.00 & 0.02 \\
\hline & Sometimes or frequently & $2.66(1.20 ; 5.90)$ & \\
\hline \multirow[t]{2}{*}{ Endosulfan } & Did not apply & 1.00 & 0.06 \\
\hline & Applied & $2.74(0.94 ; 8.04)$ & \\
\hline
\end{tabular}

95\% Cl: 95\% confidence intervals; OR: odds ratio; PPE: personal protective equipment.

The estimate of the magnitude and severity of occupational exposure to pesticides, its effects and consequences, cannot be measured exclusively by means of classical indicators of mortality and morbidity. Apparent underreporting of cases of acute pesticide poisoning ${ }^{6}$ does not reflect the true extent of the problem existing in rural areas. Some authors report as much as a $50 \%$ deficit in the reporting of these events 22 .
The prevalence of symptoms reported in our study, and the rate of activity-related medical consultation and hospitalization, show high occupational exposure, and may be categorized as indirect indicators of the level of exposure, unlike the recording of cases of pesticide poisoning. In Argentina, there were only 152 cases of agricultural pesticide poisoning reported to the National Health Surveillance System in 2009 23, with a na- 
tional reporting rate of 0.04 cases per 10,000 people. The Superintendent of Occupational Risks, the state agency charged with monitoring compliance with work health and safety standards, announced that agricultural activity in Argentina reported one of the highest indices of accidents at work $(84.7 \%$ ) , with a mortality rate of 170.7 cases per million workers covered, only surpassed by the construction and mining industry 24 . The Province of Córdoba concentrates $88 \%$ of the coverage of the labor sector in that area.

There are several factors involved in the occurrence of these high levels of accidents. The higher consumption of pesticides (kg/year), the toxicity of the products applied, the diversity of agrochemicals applied, the extent of the areas sprayed, the laxity of State control, the prevailing weather conditions and particularly the working conditions in the context of the everyday work of applicators, are among the main variables that shape the patterns of occupational exposure to pesticides. The results herein provide evidence for this hypothesis and help to analyze the risk of these events.

The association that was found between the symptoms reported, as well as increased hospitalizations and visits to doctors among those who had been exposed to certain insecticides, such as endosulfan, (as reported elsewhere 25 ), provides evidence in this regard. The exposure to multiple pesticides (mixing and/or applying more than 10 pesticides), either simultaneously or over time, is a recognized risk factor; their combination may be associated with increased toxicity in human poisoning compared to each pesticide alone; these compounds can be substrates, inhibitors and inducers of enzymes and also causative agents of various toxic effects. The combined action of pesticides needs to be addressed in the risk assessment 26 .

Symptoms reported here and the frequency of their occurrence are consistent with other reports, showing a positive correlation between health and occupational exposure to pesticides $25,26,27,28,29,30,31,32,33$. Table 5 compares the type and frequency of symptoms reported in the literature due to occupational exposure, which occurred within a range of between $12.3 \%$ and $87.5 \%$. The symptoms reported were similar to those found here: skin irritation, smarting eyes, tears, coughing and expectoration, chest pain, skin rash, blurred vision, decreased vision, runny nose, headaches, vertigo, dizziness, tiredness or weakness, tremor, muscle, joint and bone pain, loss of appetite, nausea, vomiting and diarrhea. The heat stress disorders must be considered when evaluating health conditions of agricultural workers exposed to intense sunlight and heat while working, as possible confounders. Symptoms of heat stress illness may vary according to the level of exposure, and include cramps, weakness, headaches, fatigue, confusion, and heat stroke 34 . They can be considered as a limitation of this study, since the prevailing weather conditions at the time of appearance of symptoms has not been investigated. Nevertheless, the lack of reporting of hyperthermia in the study population

Type and frequency of symptoms related to occupational pesticide exposure reported in the literature.

\begin{tabular}{|c|c|c|c|}
\hline Author (year) & Country & Frequency of occurrence of symptoms & Type of reportead symptoms \\
\hline Matos et al. 27 (2008) & Argentina & $\begin{array}{l}12.3 \text { and } 20.2 \% \text {, in flower and plant } \\
\text { growers }\end{array}$ & $\begin{array}{l}\text { Tearing, coughing and expectoration, blurred vision, } \\
\text { runny nose, nausea, vomiting and diarrhea }\end{array}$ \\
\hline Delgado \& Paumgartten 28 (2004) & Brazil & $71.0 \%$ & $\begin{array}{c}\text { Headache, nausea, decreased vision, vertigo, skin } \\
\text { irritation, loss of appetite, tremor, vomiting, diarrhea, } \\
\text { chest pain }\end{array}$ \\
\hline Mourand 30 (2005) & Palestina & $87.5 \%$ & $\begin{array}{c}\text { Burning eyes, skin rash, skin irritation, dyspnoea and } \\
\text { chest pain, dizziness and headache }\end{array}$ \\
\hline Strong et al. 29 (2004) & USA & $50.0 \%$ & $\begin{array}{l}\text { Headache, burning eyes, muscle, joint and bone } \\
\text { pain, skin rush, blurred vision, shortness of breath }\end{array}$ \\
\hline $\begin{array}{l}\text { Palacios-Nava \& Moreno- } \\
\text { Tetlacuilo } 31 \text { (2004) }\end{array}$ & México & $56.1 \%$ & Headache, stomachache, muscular pain \\
\hline Palacios-Nava 32 (2003) & México & $\begin{array}{c}27.0 \text { to } 35.0 \% \text { of the acute symptoms } \\
\text { appears within } 24 \text { hours, persistent } 15 \\
\text { days after exposure }\end{array}$ & $\begin{array}{l}\text { Tiredness or weakness, headache, muscular pain, } \\
\text { blurred vision, irritated eyes, dizziness }\end{array}$ \\
\hline Cortés-Genchi et al. 33 (2008) & México & $38.0 \%$ & Headache, itching and dizziness \\
\hline
\end{tabular}


strengthens the hypothesis of the occurrence of the informed symptoms related to their occupational pesticide exposure.

The presence of symptoms of irritation as a risk factor for pesticide exposure-related hospitalization (OR = 3.37; CI: 1.39-8.19), suggests that the main cause of hospitalization is most likely the occurrence of an acute event, particularly with the implementation of the insecticides chlorpyrifos and endosulfan (Tables 3 and 4). Nervousness or depression as a risk factor for the presence of symptoms of irritation ( $\mathrm{OR}=4.39$; CI: 2.83-6.80), as well as the presence of headaches as a risk factor for hospitalization in this study $(\mathrm{OR}=2.66$; $\mathrm{CI}$ : $1.20-5.90)$, shows the occurrence of neurotoxic manifestations.

The literature reviewed identified the great diversity of agricultural products applied and the symptomatic manifestations associated with occupational exposure, demonstrating the existence of a multiplicity of health risk scenarios, according to the different prevailing working conditions. Cortés-Genchi et al. 33 report that only $14.7 \%$ of the workers studied sought medical attention when the event occurred; the remaining $85.3 \%$ felt that their poisoning was mild and resorted to home remedies; this was one of the most common causes of underreporting of poisoning in rural areas.

The analysis of the protection level reported in this study revealed that only $32.7 \%$ of subjects were adequately protected. The proper use of PPE is a critical conditioning factor in assessing exposure and is a priority measure for epidemiological surveillance and in prevention strategies aimed at the occupationally exposed population. In an earlier study, our group showed that the proper use of PPE by applicators was associated with extreme categories of age: workers under 25 years and older than 45 years are least protected $(\mathrm{p}<$ 0.01 ), while it was not found to be associated with their level of education ( $p=0.12$ ) or marital status $(p=0.10)$ 14. The situation described here has been widely and consistently reported in the literature 35,36 . The associations observed in this study about inappropriate use of PPE and the presence of symptoms are clear evidence of occupational exposure to pesticides with adverse effects on health.

The proper use of PPE was a protective factor for symptoms of irritation $(\mathrm{OR}=0.61$; CI: 0.400.92 ), which were also associated with a lower participation of agronomists in making the prescription for plant application $(p=0.06)$. Their participation influences the organizational aspect of the tasks performed, providing a more controlled and safer working environment.

Being married or cohabiting was categorized as a protective factor for medical consultation, perhaps the result of workers' particular concep- tion of self-care in relation to their responsibility to their families. The medical consultation rate observed in this study is lower than that reported in other countries in the region, including Mexico 37, where $54.3 \%$ sought medical attention when showing signs of toxicity, five times the consultation rate seen among U.S. applicators 25 . They also reported a risk with the application of insecticides that was 70 times greater, and a positive correlation with the performance of other tasks, such as preparing the mixture to apply and repairing the spraying machinery. The same report found, as did our research, a paradoxically positive association between the higher rate of medical consultation and the proper use of PPE (OR = 1.58; CI: 1.05 2.37). This situation suggests the late adoption of protective measures and indicates a lack of primary prevention in occupational health, with the protective measures being a result of health problems that were already prevalent.

A significant positive association was also observed between the consultation rate and the use of self-propelled or towed machinery, equipped with pressurized cabins and with the entry of air through an activated charcoal filter, for applying pesticides $(p=0.02)$. To properly elucidate the significance of this requires further specific research.

The hospitalization rate reported by the applicators is more than 15 times that estimated for men aged 15 to 64 years in the general population of the province of Córdoba, for the year 2007, which was $0.34 \%$.

Time in the job was associated with symptoms of irritation $(p=0.03)$ and with more frequent medical consultation $(p<0.01)$. This finding is consistent with that reported in the yearbook of the Superintendent of Work Risks 24, different to other occupational exposures; in $65 \%$ of cases, the occupational disease becomes manifest before the first year of exposure and, within this period, the highest proportion includes those that occur during the first month under the influence of the agent $(32 \%)$. On the other hand, in agriculture, there is a notable weight of occupational diseases between the second month and the fourth year of influence of the agent, ranking above the average. This finding may explain the age distribution of our population, consisting of young subjects with a low proportion over 55 years ( $5.4 \%$ ), which could indicate that people progressively move away from this area of work, most likely due to deleterious effects on their health. It has been widely described in the literature that the general healthiness of farmers (the "healthy-worker effect") may mask potential adverse effects of farming on health 38 .

The early entry of applicators to this kind of work, some as young as 14 , shows a situation that is increased by the frequent proximity of housing 
to the workplace (cultivated fields). This leads to a non-occupational exposure for the worker after work and para-occupational exposure for the remaining family members and the communities close to areas of agrochemical spraying, as described in other reports. Gladen et al. 39 report many indirect exposure opportunities; for example, the proximity of the homes to pesticide mixing areas, the storage of pesticides in applicators homes and the habit of washing clothing worn for pesticide work in the same machine as other laundry. It should be noted that local legislation concerning agrochemicals (Provincial Law $n .9,164$ ) forbids the spraying of pesticides within 500 meters of populations, and these situations highlight the current weakness of the regulatory framework, which is of core importance to ensure both safe working environments and the healthcare of the general population.

The exposure of highly vulnerable groups, such as women of childbearing age and children at all stages of growth, must be taken into account in assessing the problem, and in approaches for tackling it 40 . While this study did not confirm a significant association between distance from the nearest dwelling to the crop, prevalence of symptoms and/or frequency of visits or hospitalizations, it could be explained by the characteristics of this kind of exposure, less intense and more prolonged, generally associated with pathologies with subtle, late clinical manifestations. However, there is local evidence of such an association in the rural setting. Research carried out in 34 rural workers' homes in the southwest of the Province of Córdoba 41, evaluated a total of 146 individuals, and found that in $34 \%$ of households there was spraying around the house, and that $35 \%$ reported conditions attributable to pesticide poisoning, $83 \%$ of which were in people who apply them. The most commonly used pesticides were glyphosate, cypermethrin, 2-4D, endosulfan, atrazine and chlorpyrifos, pesticides that have been described as having a high rate of use by Butinof et al. 42 , and in our study population.

The self-reporting technique, as applied here, and the low proportion of migrant workers, enabled us to obtain first-hand information, which was extremely valuable for analysis and for the monitoring of this cohort. The study sample size, $\mathrm{n}=880$, and the application of a previously validated instrument, has allowed us to address a very specific population group, the applicators in the Province of Córdoba, and this is the only study in Argentina to have tackled this issue at the population level. As mentioned previously, the data were collected during a period of four years, a potential limitation of this study; in this regard, previous results of our research group showed that the ex- posure context variables did not vary during the named period 43 .

The evidence presented in this paper describes a particular risk scenario whose complexity is difficult to cover from the usual approaches. Unsafe handling of chemicals, regulatory gaps, deficient legislation and control, lack of information about environmental risks, coupled with cultural patterns of perception of inevitability among the affected populations, partly explain the occurrence of these health and environmental threats in Argentina and in other countries of the region 44 .

The development of an adequate epidemiological surveillance system will allow early recognition of exposure, not only to monitor the evolution of the problem at the level of human and environmental health, but particularly to provide inputs for timely action to prevent the occurrence of damage. This requires implementing new tools in the health system, such as adequate clinical histories to capture any occupational or environmental exposure that can cause or exacerbate a health problem, particularly in populations such as the one studied here. This would also enable the identification of other cases in the family, workplace or community, and environmental data. In Argentina, this situation is improving thanks to the implementation across the country of new methodologies to improve the recording of such adverse events.

The experience of many countries has shown that the prevention of health risks from pesticides is technically feasible and economically rewarding for individuals and the community as a whole. Proper risk assessment and pesticide use management are essential components of prevention. Assessing and managing occupational health risks posed by pesticide use in agriculture is a complex but essential task for specialists in occupational health and toxicology.

\section{Conclusions}

This study is the first population-based research in Argentina which addresses the issue of pesticide exposure in rural settings, particularly among pesticide applicators of extensive crops, and its impact on their health conditions. The study shows a high prevalence of symptoms related to the task of mixing and/or applying pesticides, as well as elevated rates of related activities such as medical consultation and hospitalization, indicators of this kind of exposure.

Marital status, length of time in the job, low level of protection considering the use of PPE, combined use of different pesticides and the application of the insecticide endosulfan, among the 
occupational exposure variables, were associated with a higher frequency of reported symptoms and higher consultation rates and hospitalization.

The evidence reported gives significant information about prevailing working conditions and the effects on health that were identified. We be- lieve that its analysis can provide some guidelines to enable the development of sustainable policies for the activity and surveillance systems to ensure appropriate management of pesticides and to minimize their impact.

\section{Resumo}

Os trabalhadores agrícolas são uma população altamente vulnerável aos efeitos tóxicos da exposição a pesticidas. Este estudo transversal teve o objetivo de descrever as condições de saúde de aplicadores terrestres de pesticidas da Província de Córdoba, Argentina, suas práticas de trabalho e características sociodemográficas, por meio de um questionário padronizado autoadministrado ( $n=880)$. A análise descritiva relatou alta prevalência de sintomas ocasionais ou frequentes: 47,4\% sintomas irritativos, 35,5\% fadiga, 40,4\% dor de cabeça e 27,6\% ansiedade ou depressão. Mediante modelos logísticos foram detectados os fatores protetores e do risco que explicam a presença de sintomas irritativos, consulta médica e hospitalização. O estado civil, anos de trabalho, o nível de proteção considerando o uso de equipamentos de proteção individual, a exposição a vários pesticidas e aplicação do inseticida endosulfan, foram associados com maior frequência de sintomas, consultas médicas e hospitalização por causas relacionadas à exposição ao agrotóxico.

Praguicidas; Doenças Profissionais; Exposição Ocupacional

\section{Contributors}

M. Butinof took part in the original conception of the project, in analyzing and interpreting the results, and in drawing up the first draft. R. A. Fernandez participated in the original conception of the project, in analyzing and interpreting the results, and in writing the article; and approved the fair copy of the manuscript. M. I. Stimolo analysed the data, made a critical revision of the manuscript and made some contributions and approved the fair copy of the manuscript. M. J. Lantieri took part in the original idea of the project, made a critical revision of the manuscript and made contributions and approved the fair copy of the manuscript. M. Blanco collaborated in field work, analyzed and interpreted the data collected, made contributions, and approved the fair copy of the manuscript. A. L. Machado analyzed and interpreted the information collected, made a critical revision of the manuscript and made contributions, and approved the fair copy. G. Franchini took part in field work, made a critical revision of the manuscript and contributions, and approved the fair copy. M. P. Díaz contributed towards the original conception of the project, drew up the protocol, made a critical revision of the manuscript and contributions, and approved the fair copy.

\section{Acknowledgments}

This study was supported by grant PICT 2008-1814 from the National Agency of Technological and Scientific Promotion, through the Fund for Scientific and Technological Research (FONCYT) and by a grant (SECyT-UNC - 162/12) from the Secretary of Science and Technology, University of Córdoba. We are grateful to the Agriculture, Livestock and Food Ministry of Córdoba Province. We would also like to thank all of the workers who agreed to participate in this study. 


\section{References}

1. Dirección de Prensa, Gobierno de la Provincia de Córdoba. Presentación de valores del producto geográfico bruto de la Provincia de Córdoba año 2007. http://web2.cba.gov.ar/Web/News. nsf/vai/0000000000002500/\$FILE/Gacetilla\%20 PGB\%202007\%20.pdf (accessed on 07/Jan/2011)

2. Zak MR, Cabido M, Hodgson JG. Do subtropical seasonal forests in the Gran Chaco, Argentina have a future? Biol Conserv 2004; 120:589-98.

3. KLEFFMANNGROUP Argentina. Mercado argentino de productos fitosanitarios, 2012. http://www.casa fe.org/pdf/estadisticas/Informe\%20Mercado\%20Fi tosanitario\%202012.pdf (accessed on 19/Aug/2013).

4. Ortiz-Hernández ML, Sánchez-Salinas E, OlveraVelona A, Folch-Mallol JL. Pesticides in the environment: impacts and its biodegradation as a strategy for residues treatment. Rijeka: InTech; 2011.

5. Thundiyil JG, Stober J, Besbelli N, Pronczuk J. Acute pesticide poisoning: a proposed classification tool. Bull World Health Organ 2008; 86:205-9.

6. Litchfield MH. Estimates of acute pesticide poisoning in agricultural workers in less developed countries. Toxicol Rev 2005; 24:271-8.

7. Badii M, Landeros J. Plaguicidas que afectan a la salud humana y la sustentabilidad. CULCyT 2007; 4:21-34.

8. Bassil KL, Vakil C, Sanborn M, Cole DC, Kaur JS, Kerr KJ. Cancer health effects of pesticides: systematic review. Can Fam Physician 2007; 53:1704-11.

9. Sanborn M, Kerr KJ, Sanin LH, Cole DC, Bassil KL, Vakil C. Non-cancer health effects of pesticides: systematic review and implications for family doctors. Can Fam Physician 2007; 53:1712-20.

10. Alavanja M, Bonner MR. Occupational pesticide exposures and cancer risk: a review. J Toxicol Environ Health B Crit Rev 2012; 15:238-63.

11. Damalas C, Eleftherohorinos I. Pesticide exposure, safety issues, and risk assessment indicators. Int J Environ Res Public Health 2011; 8:1402-19.

12. Arcury TA, Quandt SA, Dearry A. Farmworker pesticide exposure and community-based participatory research: rationale and practical applications. Environ Health Perspect 2001; 109:429-33.

13. Lantieri MJ, Meyer Paz R, Butinof M, Fernández RA, Stimolo MI, Díaz MP. Exposición a plaguicidas en agroaplicadores terrestres de la provincia de Córdoba: factores condicionantes. Agriscientia 2009; 26:43-54.

14. Lantieri MJ, Butinof M, Fernández RA, Stimolo MI, Blanco M, Díaz MP. Work practices, exposure assessment and geographical analysis of pesticide applicators in Argentina. In: Stoycheva M, editor. Pesticide in the modern world: effects of pesticides exposures. Rijeka: InTech; 2011. p. 115-39.

15. Alavanja MC, Sandler DP, McMaster SB, Zahm SH, McDonnell CJ, Lynch CF, et al. The Agricultural Health Study. Environ Health Perspect 1996; 104:362-9

16. Stewart P. Challenges to retrospective exposure assessment. Scand J Work Environ Health 1999; 25:505-10.
17. Dosemeci M, Alavanja MCR, Rowland AS, Mage D, Zahm SH, Rothman N, et al. A quantitative approach for estimating exposure to pesticides in the Agricultural Health Study. Ann Occup Hyg 2002; 46:245-60.

18. Dirección de Estadísticas e Información de Salud, Secretaria de Políticas, Regulación e Institutos, Ministerio de Salud de la Nación. Sistema estadístico de salud: egresos de establecimientos oficiales por diagnóstico, año 2007. Buenos Aires: Ministerio de Salud de la Nación; 2009. (Serie 11. Estadísticas de Servicios de Salud, 3).

19. McCullagh P, Nelder JA. Generalized linear models. London: Chapman and Hall; 1989.

20. Power AG. Ecosystem services and agriculture: tradeoffs and synergies. Philos Trans R Soc Lond B Biol Sci 2010; 365:2959-71.

21. Fenske RA, Day Jr. EW. Assessment of exposure for pesticide handlers in agricultural, residential and institutional environments. In: Franklin CA, Worgan JP, editors. Occupational and residential exposure assessment for pesticides. Chichester: John Wiley \& Sons; 2005. p. 13-43.

22. Altamirano JE, Franco M, Bovi Mitre G. Modelo epidemiológico para el diagnóstico de intoxicación aguda por plaguicidas. Rev Toxicol 2004; 21:98-102.

23. Ministerio de Salud de la Nación. Boletín epidemiológico anual: 2009. http://www.msal.gov.ar/htm/ site/sala_situacion/PANELES/boletines/BEPANUAL_2009.pdf (accessed on 13/Aug/2011).

24. Unidad de Estudios Estadísticos, Gerencia de Planificación, Información Estratégica y Calidad de Gestión. Informe anual de accidentabilidad laboral 2012. http://www.srt.gob.ar/estadisticas/ anuario/2012.pdf (accessed on 20/Dec/2013).

25. Alavanja MC, Sandler DP, McDonnell CJ, Lynch CF, Pennybacker M, Zahm SH, et al. Factors associated with self-reported, pesticide-related visits to health care providers in the agricultural health study. Environ Health Perspect 1998; 106:415-20.

26. Lokke H, Ragas AM, Holmstrup M. Tools and perspectives for assessing chemical mixtures and multiple stressors. Toxicology 2013; 313:73-82.

27. Matos EL, Loria DJ, Albiano N, Sobel N, Bujan EC. Efectos de los plaguicidas en trabajadores de cultivos intensivos. Bol Oficina Sanit Panam 1988; 104:160-70.

28. Delgado IF, Paumgartten FJ. Intoxicações e uso de pesticidas por agricultores do Município de Paty do Alferes, Rio de Janeiro, Brasil. Cad Saúde Pública $2004 ; 20: 180-6$

29. Strong LL, Thompson B, Coronado GD, Griffith WC, Vigoren EM, Islas I. Health symptoms and exposure to organophosphate pesticides in farm workers. Am J Ind Med 2004; 46:599-606.

30. Mourand TA. Adverse impact of insecticides on the health of Palestian farm workers in the Gaza Strip. Int J Occup Environ Health 2005; 11:144-9.

31. Palacios-Nava ME, Moreno-Tetlacuilo LMA. Diferencias en la salud de jornaleras y jornaleros agrícolas migrantes en Sinaloa, México. Salud Pública Méx 2004; 46:286-93. 
32. Palacios-Nava ME. Aplicación de un instrumento para evaluar la exposición a plaguicidas órganofosforados, efectos agudos y subagudos en la salud de trabajadores agrícolas. Rev Fac Med UNAM 2003; 46:22-7.

33. Cortés-Genchi P, Villegas-Arrizón A, Aguilar-Madrid G, Paz-Román P, Maruris-Reducindo M, Juaréz-Pérez CA. Síntomas ocasionados por plaguicidas en trabajadores agrícolas. Rev Méd Inst Mex Seguro Soc 2008; 46:145-52.

34. Kjellstrom T, Holmer I, Lemke B. Workplace heat stress, health and productivity: an increasing challenge for low and middle-income countries during climate change. Glob Health Action 2009; 2:10.

35. Schenker MB, Orenstein MR, Samuels SJ. Use of protective equipment among California farmers. Am J Ind Med 2002; 42:455-64.

36. Macfarlane E, Chapman A, Benke G, Meaklim J, Sim M, McNeil J. Training and other predictors of personal protective equipment use in Australian grain farmers using pesticides. Occup Environ Med 2008; 65:141-6.

37. Hernández-González MM, Jiménez-Garces C, Jimenez-Albarran FR, Arceo-Guzmán ME. Caracterización de las intoxicaciones agudas por plaguicidas: perfil ocupacional y conductas de uso de agroquímicos en una zona agrícola del Estado de México, México. Revista Internacional de Contaminación Ambiental 2007; 23:159-67.

38. Waggoner JK, Kullman GJ, Henneberger PK, Umbach DM, Blair A, Alavanja MC, et al. Mortality in the Agricultural Health Study, 1993-2007. Am J Epidemiol 2011; 173:71-83.
39. Gladen BC, Sandler DP, Zahm SH, Kamel F, Row land AS, Alavanja MC. Exposure opportunities of families of farmer pesticide applicators. Am J Ind Med 1998; 34:581-7.

40. Briggs D. Indicators to improve children's environmental health. Geneva: World Health Organization; 2003.

41. Gentile N, Mañas F, Peralta L, Bosch B, Gorla N, Aiassa D. Encuestas y talleres educativos sobre plaguicidas en pobladores rurales de la comuna de Río de los Sauces, Córdoba. RETEL Rev Toxicol Línea 2010; 30:36-57.

42. Butinof M, Fernández R, Lantieri MJ, Stimolo MI, Blanco M, Machado AL, et al. Pesticides and agricultural work environments in Argentina. In: Larramendy $\mathrm{ML}$, Soloneski S, editors. Pesticides: toxic aspects. Rijeka: InTech; 2014. p. 105-34.

43. Blanco M, Lantieri MJ, Stimolo MI, Butinof M, Fernández RA, Padró O, et al. Factores condicionantes de la exposición a pesticidas de agroaplicadores por areas ecológicas homogéneas, de la Provincia de Córdoba, Argentina. Pesticidas 2013; 23:37-48.

44. Ilizaliturri Hernández CA, González-Mille D, Pelallo NA, Domínguez G, Mejía-Saavedra J, Dosal AT, et al. Revisión de las metodologías sobre evaluación de riesgos en salud para el estudio de comunidades vulnerables en América Latina. Interciencia 2009; 34:710-7.

Submitted on 30/Dec/2013

Final version resubmitted on $01 /$ Sep/2014

Approved on 18/Sep/2014 